This article was downloaded by: [Monash University Library]

On: 07 January 2015, At: 16:45

Publisher: Routledge

Informa Ltd Registered in England and Wales Registered Number: 1072954

Registered office: Mortimer House, 37-41 Mortimer Street, London W1T

3J H, UK

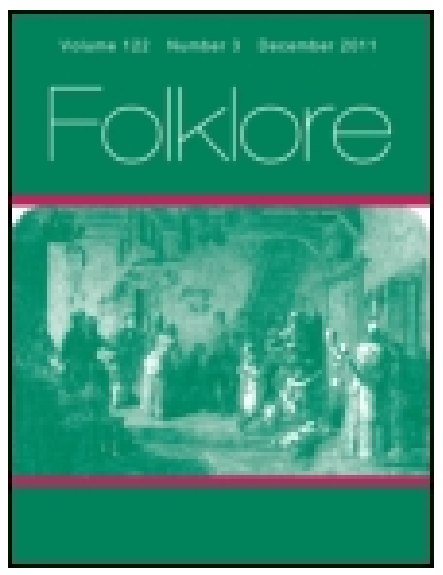

\title{
Folklore
}

Publication details, including instructions for authors and subscription information:

http:// www. tandfonline.com/loi/ rfol20

\section{Putting Out the Broom}

\author{
Wm. Self. Weeks ${ }^{a}$ \\ ${ }^{\text {a }}$ Westwood, Clitheroe \\ Published online: 14 Feb 2012.
}

To cite this article: Wm. Self. Weeks (1922) Putting Out the Broom, Folklore, 33:3, 294-296, DOI: 10.1080/0015587X.1922.9720553

To link to this article: http:// dx. doi. org/ 10.1080/0015587X.1922.9720553

\section{PLEASE SCROLL DOWN FOR ARTICLE}

Taylor \& Francis makes every effort to ensure the accuracy of all the information (the "Content") contained in the publications on our platform. However, Taylor \& Francis, our agents, and our licensors make no representations or warranties whatsoever as to the accuracy, completeness, or suitability for any purpose of the Content. Any opinions and views expressed in this publication are the opinions and views of the authors, and are not the views of or endorsed by Taylor \& Francis. The accuracy of the Content should not be relied upon and should be independently verified with primary sources of information. Taylor and Francis shall not be liable for any losses, actions, claims, proceedings, demands, costs, expenses, damages, and other liabilities whatsoever or howsoever caused arising directly or indirectly in connection with, in relation to or arising out of the use of the Content.

This article may be used for research, teaching, and private study purposes. Any substantial or systematic reproduction, redistribution, reselling, loan, sub-licensing, systematic supply, or distribution in any form to anyone is 
expressly forbidden. Terms $\&$ Conditions of access and use can be found at http://www.tandfonline.com/page/terms-and-conditions 


\section{COLLECTANEA.}

\section{Putting out the Broou.}

(Folk-Lore, vol. xxaiii. p. 34 et seqq.)

Mr. Rose, in his article on Asinus in Tegulis in the last number of Folk-Lore, refers to "the curious custom reported from Great Bookham, Surrey, of putting a broom up the chimney with its twigs protruding during the absence of the housewife." This practice existed in Clitheroe, Lancashire. The following is extracted from some articles I contributed to a local paper over thirty years ago on Clitheroe Folk-Lore :-

"It was at one time the practice (though I have never seen it done) for a man, whose wife is away from home, to stick the besom out of the window, or from the top of the chimney, in order to intimate to his friends that he is temporarily free from restraint, and that he will be free to enjoy himself. This has given rise to the saying ' When you are gone we will put the besom out and have rejoicings,' which is as much as to say, 'We shall be glad to be rid of you.' Sometimes when a man's wife is away from home, his friends, for a joke, will tie a red rag to a broom, and climb up and fix it in his chimney. I think this is more often done when the wife has deserted her husband, and it is a species of poking fun at him." The late Mr. R. C. Pilling, who spent the early part of his life in Clitheroe, corroborated this account.

There is an allusion to putting out the broom (but applied to the absence of the master of the house) in a letter dated 4th February, 1810, from Revd. Thomas Wilson, B.D., Incumbent of Clitheroe and Head Master of the Free Grammar School there, to Samuel Staniforth, Esq., of Liverpool (see Wilson's 
Miscellanies, Chetham Society, vol. xlv. p. 203), which is as follows :-

"I forgot to tell you that as the broom was out in Winckley Street [Preston] on account of our friend Cross's absence, Mrs. Mary Assheton and Miss Dale were busy making preparations for a ball, which they intended to give on Monday the 29th January before his return."

A Valentine, which may be sixty years old, now in my possession, also contains a reference to this custom.

In later days when the original significance, whatever it was, originally attached to the broom was forgotten practical jokers sometimes used other objects. One day in I886, I saw the effigy of a woman fixed in the chimney of a house in Wilkin Street, Clitheroe. I enquired, and found it was the residence of a man whose wife had run away from him, and that some of his waggish neighbours had chosen this way of emphasising his misfortune.

The following appeared in the Clitheroe Times in 1891 :-

"How is it that a husband whose wife is taking a holiday can enjoy himself the better for a clothesprop being stuck in his chimney, I find it difficult to comprehend. The problem is not simplified when that clothesprop has a barrel attached midway. And yet this was the decoration upon one of the houses, and it doubtless added considerably to the picturesque beauty of the view from neighbouring garret windows."

I think it is open to question whether putting the broom in the chimney was due to any superstitious ideas connected either with the chimney or the roof. My article, before alluded to, which was compiled from information obtained from old Clitheroe folks, gives a window as an alternative to the chimney, and where the chimney was adopted it was probably because it was a conspicuous position and afforded a convenient place in which to fix a broom. I suggest comparison should be made with the practice of attaching a broom to the mast heads of ships or other vessels to signify they are for sale.

In Brand's Popular Antiquities (ed. 1849, ii. 35 I seqg.) reference is made to an ancient custom of putting up boughs upon any. thing as an indication that it was to be sold, and the author 
adds that this, " if I do not much mistake, is also the reason why an old besom (which is a sort of dried bush) is put up at the top-mast head of a ship or boat when she is to be sold." If we are to regard the broom as a substitute for a bush, then putting it out may perhaps be connected with the Tavern Keepers' bush, which, originally intended to indicate that ale was sold in his house, was no doubt associated in the public mind with the jovial entertainment to be found within.

Wy. Self. Weeks.

Westwood, Clitheroe.

The Easter Island Figures.

(Folk-Lore, vol. xxxi. p. 294 et seqq.; vol. xxxii. p. 70 et segq.)

The letters of Dr. W. H. R. Rivers and Mr. Henry Balfour on the nature of the head-dresses of the stone statues of Easter Island are of great interest, and raise questions of importance far beyond the bounds of Easter Island and the Solomons. Mr. Balfour asks whether cylindrical hats, such as Dr. Rivers suggests as the originals of the stone cylinders of Easter Island, have ever been recorded as being worn in the Pacific. I do not know whether they have been recorded in the Solomons, but they were certainly in use in New Caledonia, as is shown by Hodge's drawing, now displayed at Greenwich Hospital, of a man from that island wearing such a head-dress. This portrait is reproduced and is easily accessible in the official account of Cook's second voyage, and also in George Forster's account. Though such a head-dress has never been recorded as worn by the Maoris, it occurs occasionally on tekoteko, ancestral figures carved in wood and placed on the gables of village store-houses. An excellent example is figured in Dominion Museum Bulletin I (1905), Fig. W., where it is described by the late Augustus Hamilton as follows: "The central-specimen is of special interest as it wears the curious high cap or ornament frequently seen in carvings in this district [Rotorua], recalling the crownsor caps of the Easter Island stone figures." It is vertical behind, but in front it slopes out slightly in the lower part a little above 